\title{
EFFECT OF CALCIUM IONS TO THE ACTIVITY AND STABILITY OF EXTRACELLULAR LIPASE PRODUCED BY MODERATE HALOPHILIC BACTERIA Halomonas meridiana BK-AB4
}

\author{
GALO AYU MEGGA NANDA and RUKMAN HERTADI* \\ Department of Chemistry, Faculty of Mathematics and Natural Sciences \\ Institut Teknologi Bandung, Jl. Ganesha 10, Bandung 40132, Indonesia \\ *E-mail: rukman@chem.itb.ac.id
}

Accepted 27 April 2020, Published online 6 July 2020

\begin{abstract}
This study reported the isolation and biochemical studies of extracellular lipase produced by a moderate halophilic bacterium, Halomonas meridiana BK-AB4. The estimated molecular weight of the lipase BK-AB4 is about $50 \mathrm{kDa}$. The study of metal ions effect to the enzyme activity revealed the strong dependency towards the presence of $\mathrm{Ca}^{2+}$ ion. Further studies showed that the optimum $\mathrm{pH}$ of the enzyme was similar in the presence and the absence of $\mathrm{Ca}^{2+}$ ions. However, the presence of $\mathrm{Ca}^{2+}$ ions could improve the enzyme thermal stability as indicated by the shift of its optimum temperature from $45^{\circ} \mathrm{C}-50^{\circ} \mathrm{C}$. The addition of $\mathrm{Ca}^{2+}$ ions was also enhancing residual activity towards various inhibitors, such as SDS and PMSF up to 55\% and $68 \%$, respectively. Another interesting effect of the addition of $\mathrm{Ca}^{2+}$ ions were noted when various organic solvents were added to the enzyme solution in the ratio of $1: 1$. The activity of the enzyme increased up to $122 \%$ and $126 \%$ relative to the control when methanol and n-butanol were added, respectively. This study thus showed that the addition of $\mathrm{Ca}^{2+}$ ion not only improved the catalytic activity of lipase BK-AB4 but also made the enzyme more tolerable against various perturbations.
\end{abstract}

Key words: Extracellular lipase, halophilic bacteria, Halomonas meridiana BK-AB4, metal ions activator

\section{INTRODUCTION}

Lipase (EC 3.1.1.3) is an enzyme that catalyzes the hydrolysis reaction of ester bonds in triacylgliseride to produce fatty acids and glycerol and is able to catalyze the reverse reaction, which is synthesis of esters of free fatty acids and glycerol or another substrate (Pera et al., 2006). Lipase with esterase activity has been intensively used in various industries, such as the industry for biodiesel production. Biodiesel is a product of the transesterification reaction between triacylgliseride and alcohol. Ester synthesis and transesterification reaction catalyzed by lipase occurred in an organic environment containing a small amount of water (Pera et al., 2006). Therefore, searching the source of lipase that has high tolerance in wide range of organic solvent polarity is still intensively carried out.

One approach to obtain organic solvent tolerant lipase is to isolate it from extremophile micro-

* To whom correspondence should be addressed. organisms that live in habitats with low water activity that is similar to the organic solvents-rich environment. Microorganisms that are able to adapt to the habitat with high salinity is known as halophilic microorganisms. The results of several studies showed that some halophilic microorganisms have potential to produce lipase that stable in high temperature, high $\mathrm{pH}$, and organic solvents (Guzman et al., 2008).

Indonesia is a vast archipelago country that has many types of halophilic habitats including marine and terrestrial ones. One of the unique terrestrial halophilic habitats in Indonesia is a mud crater situated in Purwodadi region in the Central Java. This crater is periodically spitting brine to the surface despite its location is far from the sea. In the previous studies, we have isolated and identified six bacterial isolates based on their potential to produce extracellular lipase (Parwata et al., 2014; Asy'ari et al., 2014). The six bacterial isolates are Pseudomonas stutzeri BK-AB12, Pseudomonas alcalipila BK-AG13, Chromohalobacter japonicus BK-AB18, Halomonas eurihalina BK-AB15, 
Halomonas elongata BK-AB8, and Halomonas meridiana $\mathrm{BK}-\mathrm{AB} 4$. Lipases from hree of these six halophilic bacteria have been isolated and characterized and among them are lipases from Pseudomonas stutzeri BK-AB12 (Parwata et al., 2014), Chromohalobacter japonicus BK-AB 18 (Hertadi \& Widhyastuti, 2015), and Halomonas eurihalina BK-AB15 (Pangesti, 2015) showing dependency towards metal ions and better stability in various organic solvents.

Parwata et al. (2014) has studied that lipase isolated from Pseudomonas stutzeri BK-AB12 is one of the potential organic solvent stable lipase. Pseudomonas stutzeri BK-AB12 is a lower halophilic bacterium that can live in the environment with the salt concentration in the range of $0.1 \%-7.5 \%$. Lipase from Pseudomonas stutzeri BK-AB12 has activity within temperatures range of $25-70^{\circ} \mathrm{C}$, pH range of $6.0-10.0$, and showing its dependency towards $\mathrm{Ca}^{2+}$ ion which can increase the relative lipase activity of up to $27 \% . \mathrm{Ca}^{2+}$ ion binding was also able to increase the enzyme activity and stability in various organic solvents such as n-hexane, n-propanol, and isoamyl alcohol.

We also have studied lipase isolated from the moderate halophilic bacteria, Chromohalobacter japonicus BK-AB18. This lipase has a working temperature in the range of $25-85^{\circ} \mathrm{C}, \mathrm{pH}$ range of 4.0-11.0, and also showed the dependency on the presence of $\mathrm{Ca}^{2+}$ ion as its activity increased up to $74 \%$. In the presence of this activator the relative activity of lipase in organic solvents, such as nhexane, isoamyl alcohol, and chloroform, increased (Hertadi \& Widhyastuti, 2015). Lipase from the other moderate halophilic bacteria, Halomonas eurihalina $\mathrm{BK}-\mathrm{AB} 15$, was also studied. This lipase has activity at temperature range of $25-80^{\circ} \mathrm{C}, \mathrm{pH}$ range of 5.0-10.5 and the enzyme activity is also enhanced by the presence of $\mathrm{Ca}^{2+}$ ion. This activator also improved the relative activity in various organic solvents, such as n-hexane, n-butanol, and chloroform and tolerant of SDS (Pangesti, 2015).

Description biochemical properties of the three lipases above shows that each lipase have different characteristics even though they were endogenous from the same habitat and are also affected by the same ion as the activator. Therefore, it is still necessary to perform study on extracellular lipase produced by different halophilic bacteria in order to determine variations in biochemical properties of their lipase. Collection of many lipase variants will become a useful database to accommodate the industrial needs. In the present study, we used another halophilic bacteria Halomonas meridiana BK-AB4 as a source of lipase. This bacterium belongs to the class of moderate halophilic bacteria or medium category with salt tolerance range from 0.5 to $22.5 \%$. In this study we showed that this bacterium produces lipase with different biochemical and biophysical properties such as those described above.

\section{MATERIALS AND METHODS}

\section{Materials}

All inorganic salts, such as $\mathrm{NaCl}, \mathrm{CaCl}_{2}, \mathrm{MgCl}_{2}$, $\mathrm{KCl}$, and buffer components, such as phosphate and Tris-HCl were purchased from Merck. Organic solvents, such as methanol, ethanol, propanol, nhexane were also purchased from Merck. Medium components, such as yeast extract, peptone and lipase substrate pNPD (p-nitrophenyl decanoate) were purchased from Sigma.

\section{Methods \\ Bacterial cultivation \\ Halomonas meridiana BK-AB4 was cultivated in Luria Bertani (LB) medium containing 0.1\% tryptone, $0.05 \%$ yeast extract, and $10 \% \mathrm{NaCl}$. The bacterial culture was incubated at $37^{\circ} \mathrm{C}$ with $150 \mathrm{rpm}$ agitation rate for overnight. \\ Growth and lipase activity profile of Halomonas meridiana $\mathrm{BK}-\mathrm{AB} 4$}

As much as $1 \%(\mathrm{v} / \mathrm{v})$ of the overnight culture Halomonas meridiana $\mathrm{BK}-\mathrm{AB} 4$ was transferred into a fresh medium containing $0.5 \%$ peptone, $0.5 \%$ yeast extract, $0.05 \% \mathrm{CaCl}_{2}$, and $5 \% \mathrm{NaCl}$, which is later called as the production medium. The culture medium was incubated at $37^{\circ} \mathrm{C}$ with the agitation rate of $150 \mathrm{rpm}$ for 24 hours. Bacterial growth was monitored every hour by measuring the optical density at $600 \mathrm{~nm}$ with UV/Vis spectrophotometer. The crude enzyme was also monitored every hour by measuring its activity using pNPD as the substrate. Procedure to measure the enzyme activity is described below.

\section{Production and partial purification of lipase}

A single colony of the selected bacteria was grown in a $10 \mathrm{~mL}$ starter medium containing $0.5 \%$ peptone, $0.5 \%$ yeast extract, $0.05 \% \mathrm{CaCl}_{2}$, and $5 \%$ $\mathrm{NaCl}$. The medium was then incubated at $37^{\circ} \mathrm{C}$ with the agitation rate at $150 \mathrm{rpm}$ for 24 hours. A total of $1 \%(\mathrm{v} / \mathrm{v})$ of the starter culture was subsequently transferred into the production medium and incubated at $37^{\circ} \mathrm{C}$ in a rotary incubator with the agitation rate at $150 \mathrm{rpm}$ for 14 hours. The crude extract of lipase was then separated from bacterial cell using cold centrifugation at $10^{4} \mathrm{rpm}$ for 30 minutes.

Purification of lipase was carried out as described by Scopes (1994). The crude extract of lipase was partially purified with ammonium sulfate precipitation method. Three sequential ammonium 
sulfate concentration ranges were used; $0-30 \%, 30-$ $60 \%$, and $60-70 \%$. Adding the ammonium sulfate solution gently to the crude extract, while stirring until the saturation reached about $30 \%, 60 \%$ and $70 \%$, carried out the precipitation. The mixture was allowed to stand for 30-60 minutes and then it was centrifuged at $10^{4} \mathrm{rpm}$ for 30 minutes at $4^{\circ} \mathrm{C}$. The supernatant was separated from the precipitated proteins for the subsequent fractionation. The precipitated proteins in each fraction were dissolved by $50 \mathrm{mM}$ buffer phosphate $\mathrm{pH} 8.0$ and then they were dialyzed using $20 \mathrm{mM}$ with the same buffer. The lipase activity in each fraction was measured as described below.

\section{Measurement of specific activity for extracellular lipase BK-AB4}

Lipase activity was measured following the procedure described by Lee et al. (1999). The substrate emulsion was prepared by mixing $10 \mathrm{mM}$ pNPD (p-nitrophenyl decanoate) and the mixture of buffer and ethanol in the ratio of 1:95:4 (v/v/v). A total $50 \mu \mathrm{L}$ of the enzyme solution was added to 550 iL of the substrate emulsion, and then immediately incubated at a given temperature for a certain time (minutes). Activity was determined by measuring the absorbance of pNP (p-nitrophenol) at $405 \mathrm{~nm}$. Lipase activity was expressed in units/mg, which is defined as the imole product ( $\mathrm{p}$-nitrophenol) produced by the catalytic activity of lipase per minute per mg of the enzyme.

Protein concentration was determined using Bradford method (1976). Enzyme solution was reacted with Bradford reagent in ratio of $1: 1(\mathrm{v} / \mathrm{v})$. After that, the mixture was incubated for 5 minutes at room temperature and the absorbance was measured at $595 \mathrm{~nm}$ (Bradford, 1976).

\section{SDS PAGE, zymography, and determination molecular weight of lipase}

SDS PAGE, staining and distaining methods were carried out following the standard protocol described by Sambrook and Russel (2001). The gel was analyzed with the zymography method by incubating it in $50 \mathrm{mM}$ of a buffer solution containing $3 \mathrm{mM} \alpha$-naphthyl acetate and $1 \mathrm{mM}$ fast blue. The positive result was indicated by the appearance of brown band on the gel. For the determination of molecular weight of lipase, proteins left the SDS PAGE gel renatured using 100 $\mathrm{mM}$ phosphate buffer $\mathrm{pH} 8.0$ containing $0,5 \%$ triton $\mathrm{X}-100$ for 4 hours at $4{ }^{\circ} \mathrm{C}$. The gel was incubated in $50 \mathrm{mM}$ buffer solution containing $3 \mathrm{mM}$ fast blue dye and $1 \mathrm{mM} \alpha$-naphthyl acetate at the optimum temperature for 8 hours (Soliman et al., 2007).
Effect of metal ions and inhibitor on lipase activity Effect of metal ions and inhibitors on the lipase activity was studied by incubating the enzyme in $50 \mathrm{mM}$ phosphate buffer $\mathrm{pH} 8.0$ containing $5 \mathrm{mM}$ metal ions and inhibitor: $\mathrm{Ba}^{2+}, \mathrm{Ca}^{2+}, \mathrm{Mg}^{2+}, \mathrm{Zn}^{2+}$, $\mathrm{Ni}^{2+}, \mathrm{K}^{+}, \mathrm{Co}^{2+}, \mathrm{Fe}^{2+}, \mathrm{Fe}^{3+}$, EDTA, SDS and PMSF at $45^{\circ} \mathrm{C}$ for one hour (Uttatree et al., 2010). Lipase activity was assayed following the same procedure as described above. As a control, the metal ion solution was replaced with phosphate buffer.

\section{Effect of pH and temperature on lipase activity}

Effect of $\mathrm{pH}$ on lipase activity was studied at $45^{\circ} \mathrm{C}$ using $50 \mathrm{mM}$ buffer with a $\mathrm{pH}$ range from 5.0 to 10.0 . The buffer solution used in this study was acetate buffer ( $\mathrm{pH} 5.0)$, phosphate buffer $(\mathrm{pH} 6.0$ $8.0)$, tris- $\mathrm{HCl}$ buffer ( $\mathrm{pH} 8.5-9.0)$, glycine- $\mathrm{NaOH}$ buffer ( $\mathrm{pH}$ 9.5-10.0). Effect of temperature on lipase activity was determined by measuring lipase activity at various temperatures in the range from $25-70^{\circ} \mathrm{C}$. Lipase activity was assayed following the same procedure as described above.

\section{Effect of organic solvents on lipase activity}

Effect of organic solvents on lipase activity was evaluated by incubating enzyme and organic solvents in the ratio $1: 1$ at $45^{\circ} \mathrm{C}$ for 30 minutes. Lipase activity was assayed following the same procedure as described above. Organic solvents used were methanol, ethanol, 2-propanol, n-butanol, acetonitrile, acetone, chloroform and n-hexane. As a control, reagents were replaced with phosphate buffer.

\section{Effect of $\mathrm{Ca}^{2+}$ on lipase activity}

Effect of $\mathrm{Ca}^{2+}$ on lipase activity was studied by incubating the enzyme in $50 \mathrm{mM}$ phosphate buffer pH 8.0 containing $5 \mathrm{mM} \mathrm{Ca}^{2+}$ ion at $45^{\circ} \mathrm{C}$ for one hour in various conditions, such as $\mathrm{pH}$, temperature optimum, organic solvents, inhibitors, and thermal stability. Lipase activity was assayed following the same procedure as described above. As a control, lipase activity was assayed without the addition of $\mathrm{Ca}^{2+}$ ion.

\section{RESULTS AND DISCUSSION}

The growth profile and lipase activity of Halomonas meridiana BK-AB4

The growth curve of lipase was prepared by measuring optical density of the bacterial cell every hour at $600 \mathrm{~nm}\left(\mathrm{OD}_{600}\right)$ and lipase activity was measured every hour of the cultivation period in the production medium up to 21 hours at $37^{\circ} \mathrm{C}$ with the 
agitation rate at $150 \mathrm{rpm}$. The growth profile showed that the initial lag phase was observed for about 2 hours, before it enters seven-hours of log phase period, where the OD600 sharply increased from 0.1 to 1.7. After the log phase, the bacterial cell enters the stationary phase for about 20 hours (Figure 1). Some studies showed that the bacteria maximally produced the extracellular lipase in the stationary phase (Li \& Yu, 2012). In our study, lipase was also maximally produced in the stationary phase, specifically at $14^{\text {th }}$ hours of the cultivation period.

\section{Estimating molecular weight and purification of lipase from isolated bacteria}

The crude extract of the enzyme was purified with ammonium sulfate fractionations. The activity of lipase was quantified as a specific activity, which is a unit activity per $\mathrm{mg}$ of a total protein, and the best specific activity was found in the fraction of $30-60 \%$ (Table 1). We then used lipase in fraction $30-60 \%$ ammonium sulfate for further characterization.
In order to identify molecular weight of the partially purified lipase, we used SDS-PAGE and zymography methods (Figure 2). The results showed that the estimated molecular weight of lipase was about $50 \mathrm{kDa}$. The electrophoregram (Figure 2B) showed one band in all fractions indicating that there was only one type of active lipase in each fraction.

\section{Effect of metal ions on lipase activity}

Some enzyme requires metal ion as cofactor to improve its catalytic capacity. Adding various metal ions to the solution of lipase BK-AB4 gave different effects to the activity of the enzyme. The addition of $\mathrm{Ni}^{2+}, \mathrm{Zn}^{2+}, \mathrm{Co}^{2+}$, dan $\mathrm{Fe}^{3+}$ ions reduced the enzyme activity significantly, while adding $\mathrm{K}^{+}$, $\mathrm{Mg}^{2+}$ dan $\mathrm{Fe}^{2+}$ ions gave less effect to the activity (Figure 3). When $\mathrm{Ba}^{2+}$ and $\mathrm{Ca}^{2+}$ ions were added, however, the enzyme activity increased by about $116 \%$ and $124 \%$ relative to the control. As described above, metal ions exhibited different levels of effect on the lipase BK-AB4 activity.

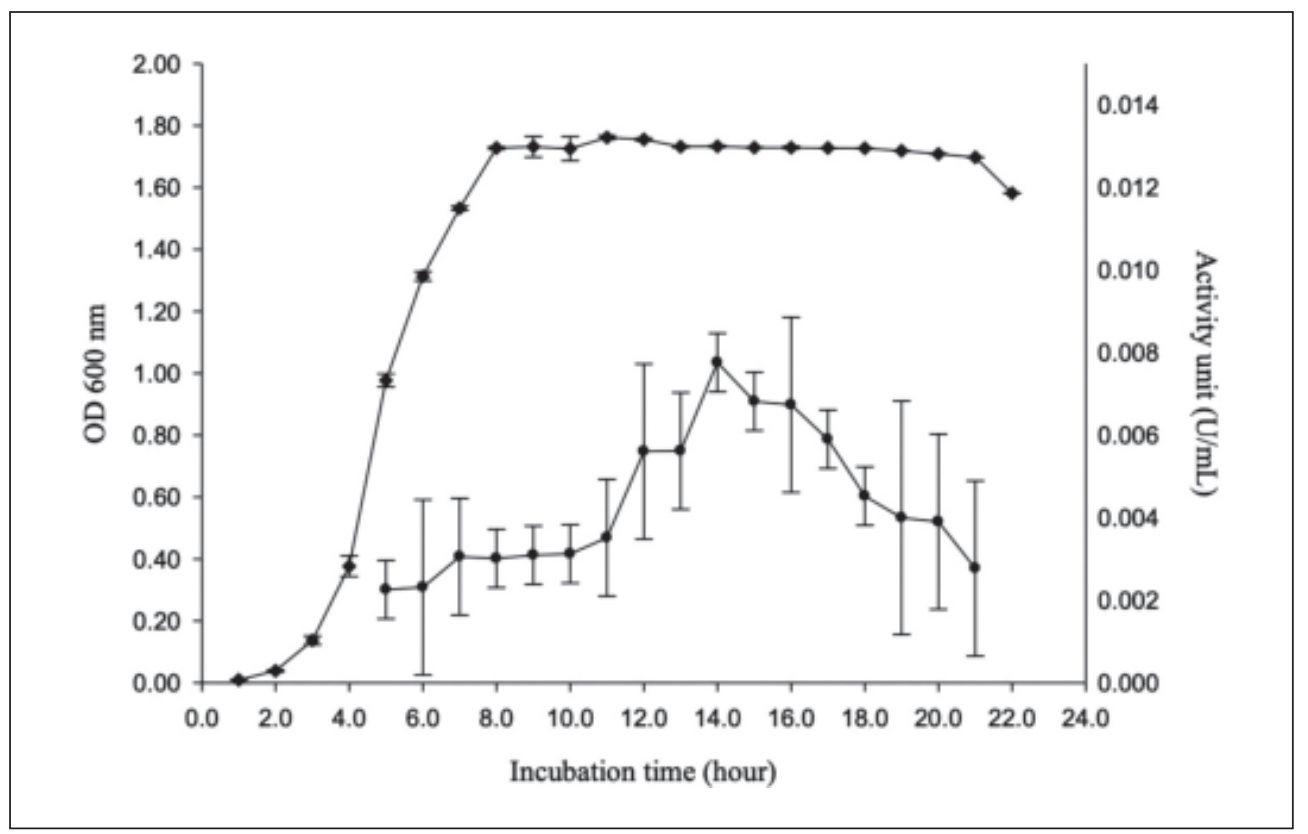

Fig 1. The growth and activity profiles of Halomonas meridiana BK-AB4 and its extracellular lipase.

Table 1. Ammonium sulfate fractionations of lipase produced by Halomonas meridiana BK-AB4

\begin{tabular}{cccc}
\hline $\begin{array}{c}\text { Ammonium Sulfate } \\
\text { Concentration Range }\end{array}$ & $\begin{array}{c}\text { Total Protein } \\
(\mathrm{mg} / \mathrm{mL})\end{array}$ & $\begin{array}{c}\text { Activity Unit } \\
(\mathrm{U} / \mathrm{mL})\end{array}$ & $\begin{array}{c}\text { Specific Activity } \\
(\mathrm{U} / \mathrm{mg})\end{array}$ \\
\hline Crude Extract & $0.040 \pm 0.003$ & $0.0015 \pm 0.006$ & $0.038 \pm 0,006$ \\
$0-30 \%$ & $0.142 \pm 0.022$ & $0.0106 \pm 0.024$ & $0,075 \pm 0.024$ \\
$30-60 \%$ & $0.123 \pm 0.008$ & $0.0389 \pm 0.003$ & $0.315 \pm 0.003$ \\
$60-70 \%$ & $0.131 \pm 0.005$ & $0.0400 \pm 0.003$ & $0.304 \pm 0.003$ \\
\hline
\end{tabular}

1 Unit defined as $1 \mu \mathrm{mol}$ p-nitrophenyl hidrolized per minutes. 


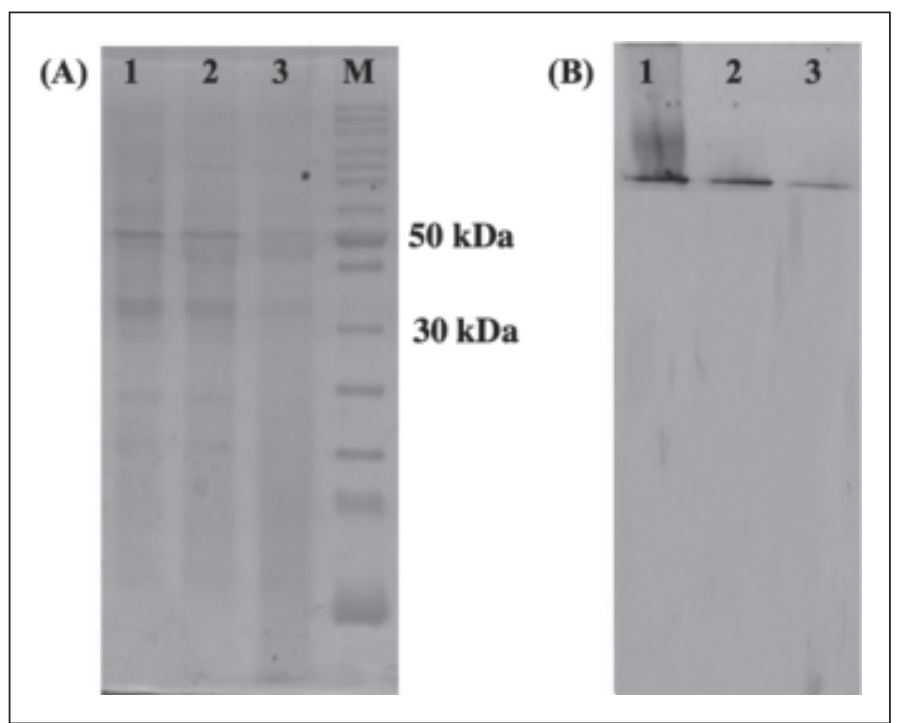

Fig 2. Electrophoregram of SDS-PAGE (A) and zymography (B) lipase. Lane 1, 2, 3, and $\mathrm{M}$ for $0-30 \%$ fraction, 30-60\% fraction, 60 $70 \%$ fraction, and Marker.

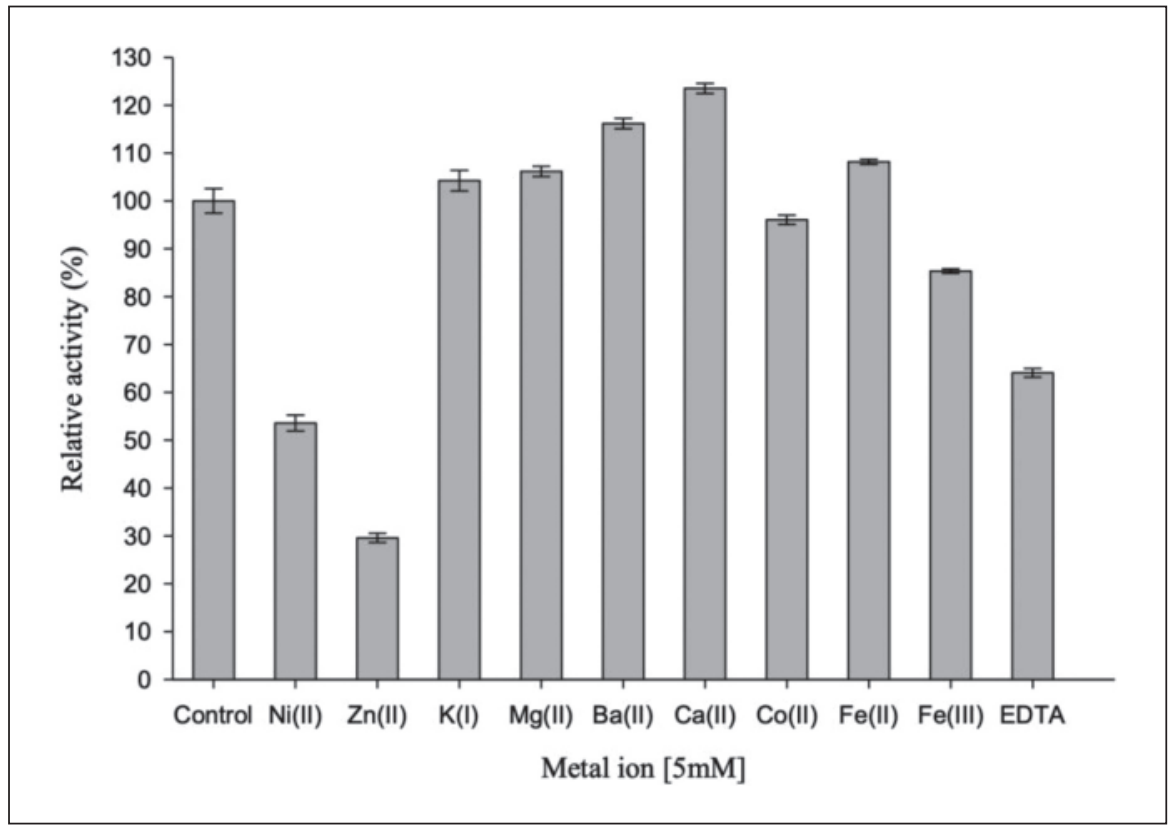

Fig 3. The activity of lipase in the presence various metal ion.

In order to evaluate whether the lipase is true metaloenzyme, we added EDTA (ethyldiaminetetraacetic acid) as chelating agent to the enzyme solution. The result showed that the activity of lipase decreases by about $36 \%$, thus it can be predicted that the activation of lipase by some ions apparently was not occurred via a complex formation with residues inside the active site of the enzyme (Parwata et al., 2014). Variation of lipase activity upon the addition of various metal ions revealed that different ion induced different level of conformational change to the enzyme (Hertadi \& Widhyastuti, 2015). Because $\mathrm{Ca}^{2+}$ ion gave the highest improvement to the enzyme activity, we further studied the effect of the presence and the absence of $\mathrm{Ca}^{2+}$ ion to biochemical and biophysical property of the enzyme.

Effect of $\mathrm{Ca}^{2+}$ ion to the activity of lipase BK-AB4 in various $\mathrm{pH}$ and temperature

Effect of $\mathrm{pH}$ on lipase activity was studied in $\mathrm{pH}$ range of 5.0-10.0 (Figure 4). By visual 


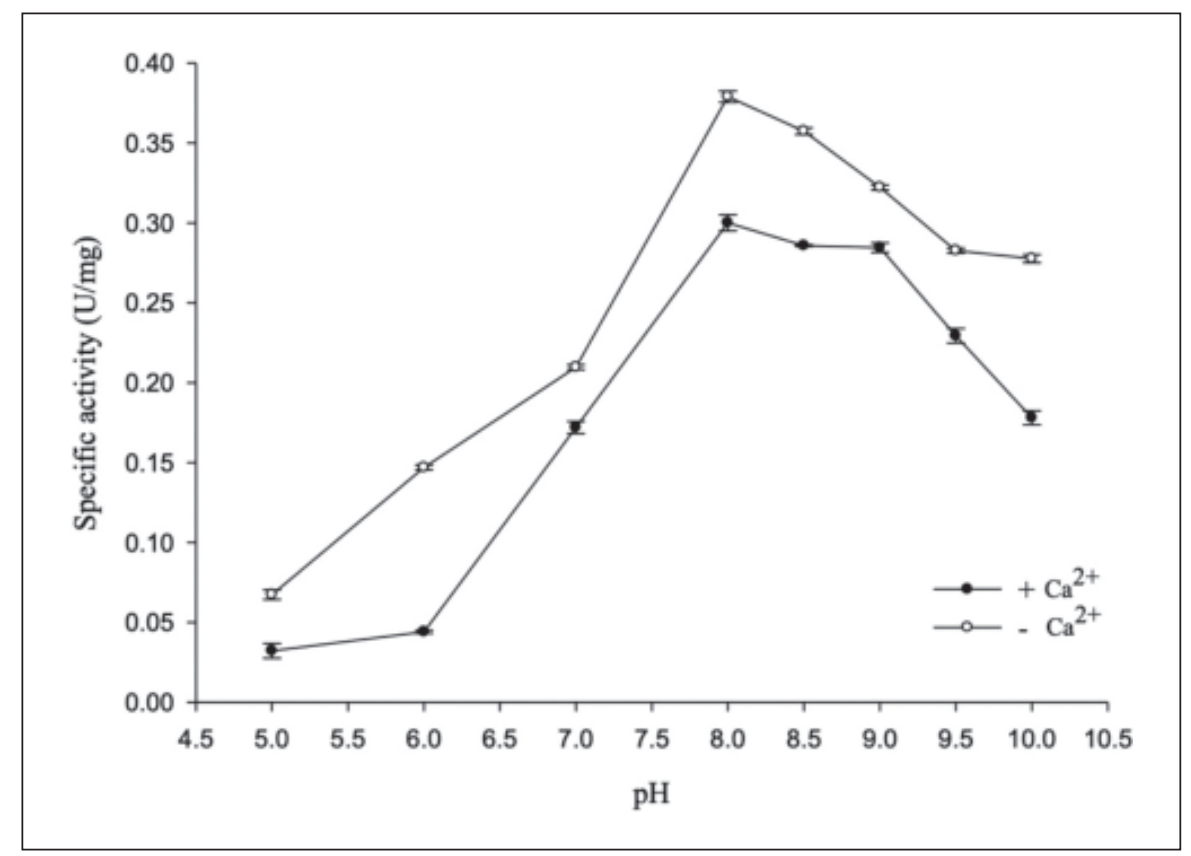

Fig 4. Profil of $\mathrm{pH}$ dependence to the activity of lipase BK-AB4 at the condition presence and absence addition $\mathrm{Ca}^{2+}$ ion.

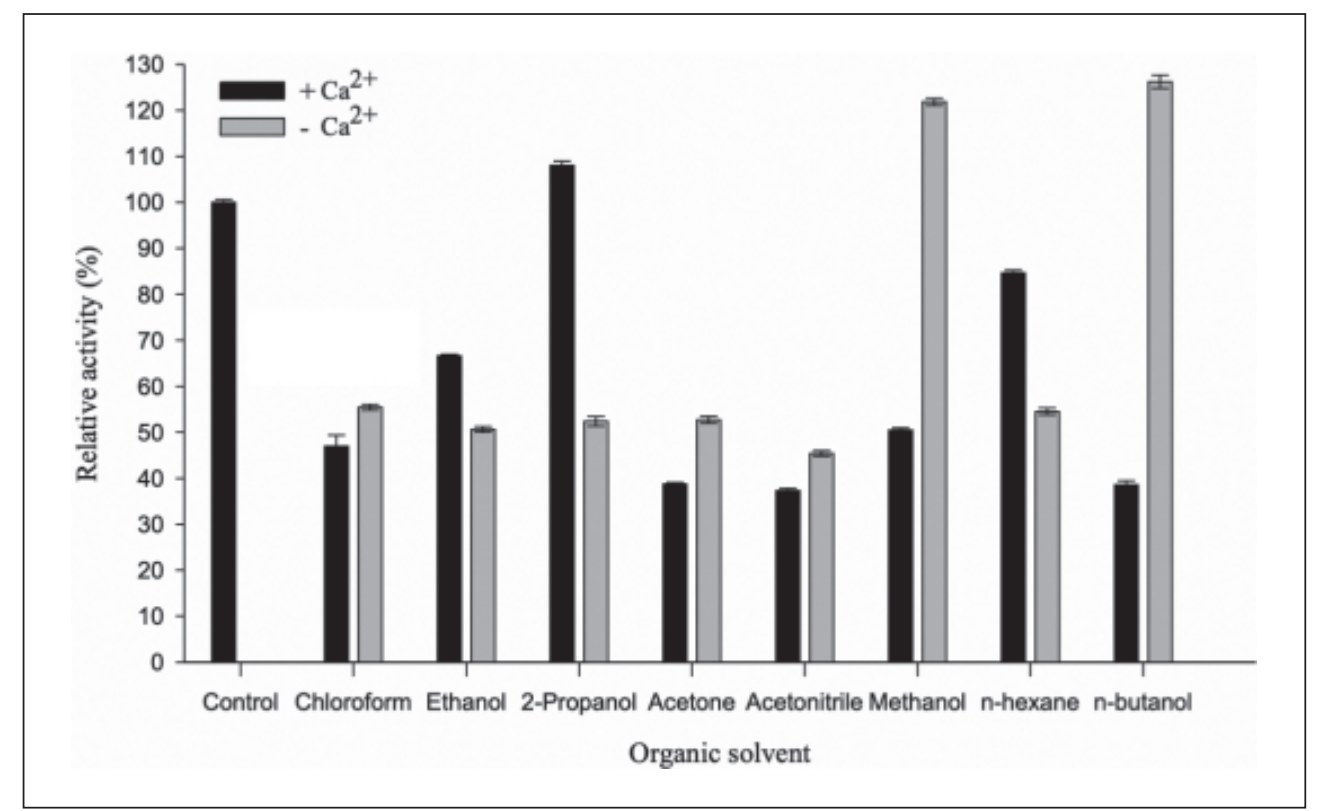

Fig 5. Profile of temperature dependence to the activity of lipase BK-AB4 at the condition presence and absence addition $\mathrm{Ca}^{2+}$ ion.

inspection, the activity of lipase BK-AB4 in the presence of $\mathrm{Ca}^{2+}$ was higher within $\mathrm{pH} 5.0$ to 10.0 but the optimum $\mathrm{pH}$ was relatively similar, in both conditions it was observed around $\mathrm{pH}$ 8. Most of lipase has the optimum activity around $\mathrm{pH} 7.0$ to 10.0 (Parwata et al., 2014; Uttatree et al., 2010; Kanjanavas et al., 2010; Ozcan et al., 2009). The effect of $\mathrm{pH}$ on the catalytic activity of lipase mainly affects the electrostatic potential of the surface and the catalytic site of enzymes. In the optimum $\mathrm{pH}$, the electrostatic potential of protein surface and its catalytic site is in optimum state to support binding of its substrate, stabilizing the transition state, as well as increasing the releasing rate of the product (Parwata et al., 2014).

Effect of temperature on lipase activity was studied in the temperature range of $25.0-75.0^{\circ} \mathrm{C}$ (Figure 5). Different profiles on the temperature dependency were observed at the condition with and without the addition of $\mathrm{Ca}^{2+}$ ion. Without the 
addition of $\mathrm{Ca}^{2+}$ ion, the highest activity occurred at $45^{\circ} \mathrm{C}$ but after the addition of $\mathrm{Ca}^{2+}$ ion the highest activity was at $50^{\circ} \mathrm{C}$. This analysis thus suggested that the effect of $\mathrm{Ca}^{2+}$ ion has improved the thermal stability of the enzyme.

\section{Effect of $\mathrm{Ca}^{2+}$ ion to the activity of lipase BK-AB4 in various organic solvents}

Stability of lipase in organic solvents was studied by measuring the enzyme activity in a $1: 1$ mixture of aqueous and organic solvent. The component of organic solvent varied from polar to non-polar ones. The result showed the activity of lipase has different dependency against the solvent polarity in the condition with and without the addition of $\mathrm{Ca}^{2+}$ ion (Figure 6).

Without the addition of $\mathrm{Ca}^{2+}$ ion, lipase BKAB4 activity reduced significantly when chloroform, ethanol, acetone, acetonitrile, methanol, and n-butanol, except n-propanol were used as the organic solvent component. Polar organic solvents generally impose negative effect on lipase activity because they can attract water layer surrounding an enzyme, thereby lowering its catalytic function (Parwata et al., 2014; Wehtje \& Adlercreitz, 1997), while nonpolar ones typically disrupt the hydrophobic interactions in the protein's core. The addition of $\mathrm{Ca}^{2+}$ ion showed significant enhancement in the relative enzyme's activity when methanol and n-butanol were used as organic solvent component up to $122 \%$ and $126 \%$ but in the rest of the solvents, its activity decreased.
The enhanced relative activity of lipase BK-AB4 in the presence of methanol, shows that this enzyme has potential to be applied as biocatalyst for transesterification reaction in biodiesel production.

\section{Effect of $\mathrm{Ca}^{2+}$ ion to the activity of lipase BK-AB4 in various inhibitors}

Effect of organic inhibitors such as SDS and PMSF on lipase activity was also studied in our study. PMSF (phenylmethylsulphonyl fluoride) was employed to identify the type of hydrolase group of lipase BK-AB4. The result showed that the addition of PMSF reduced the relative activity of lipase (Figure 7) in either with or without the addition of $\mathrm{Ca}^{2+}$ ion. PMSF inhibits the activity by interacting with a serine residue in the active site of the enzyme suggesting that lipase BK-AB4 is included in the serine hydrolase group. Similar to PMSF, the addition of SDS (sodium dodecyl sulfate), an anionic surfactant, also reduced the activity of the enzyme either with or without the addition of $\mathrm{Ca}^{2+}$ ions. SDS molecules inhibited the activity by perturbing lipid-water interface, which is very vital for the enzyme functions (Parwata et al., 2014; Gupta et al., 2004). In addition, this surfactant also weakens the hydrophobic core of the protein that might partially denature the protein. However, it was noted that the addition of $\mathrm{Ca}^{2+}$ ion was able to maintain its relative activity up to $55 \%$ suggesting that $\mathrm{Ca}^{2+}$ ion binding contributed to the extra stability of the protein against the surfactant perturbation.

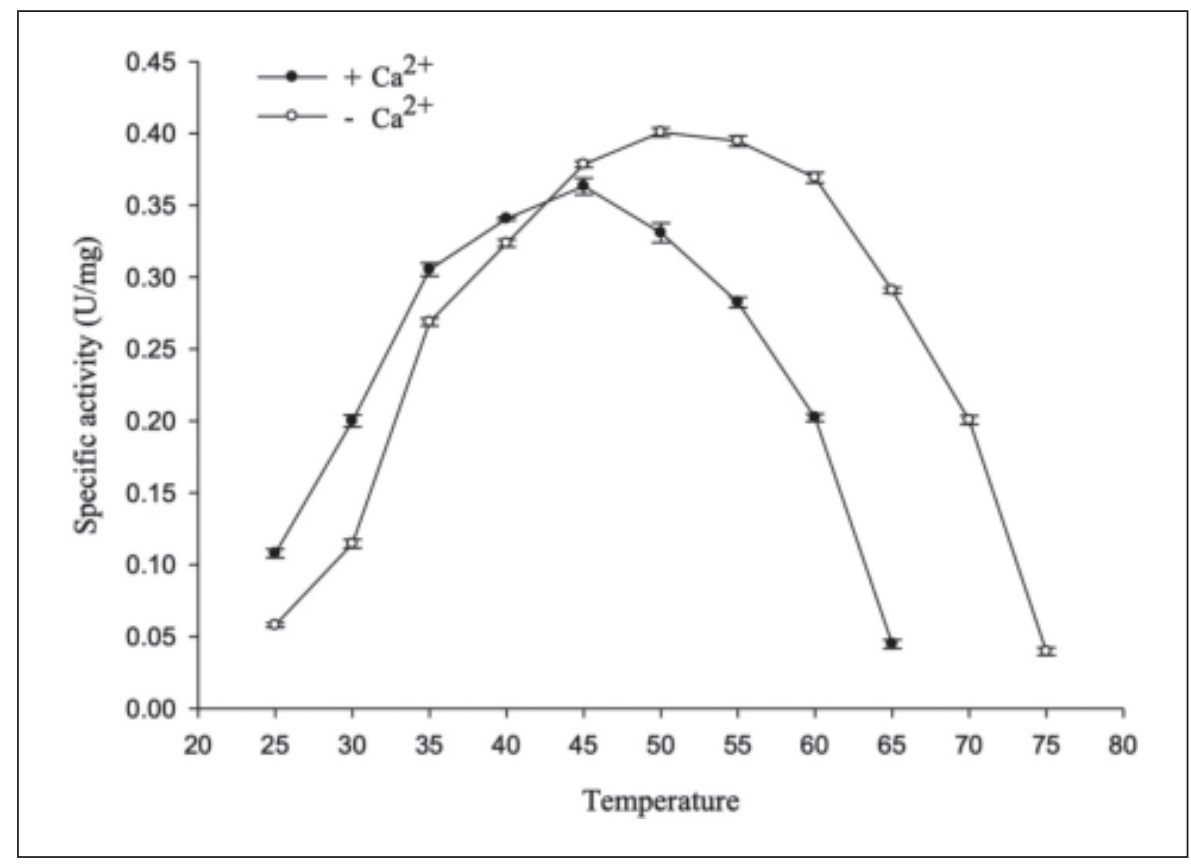

Fig 6. Profile of organic solvent dependence to the activity of lipase BK-AB4 at the condition presence and absence addition $\mathrm{Ca}^{2+}$ ion. 


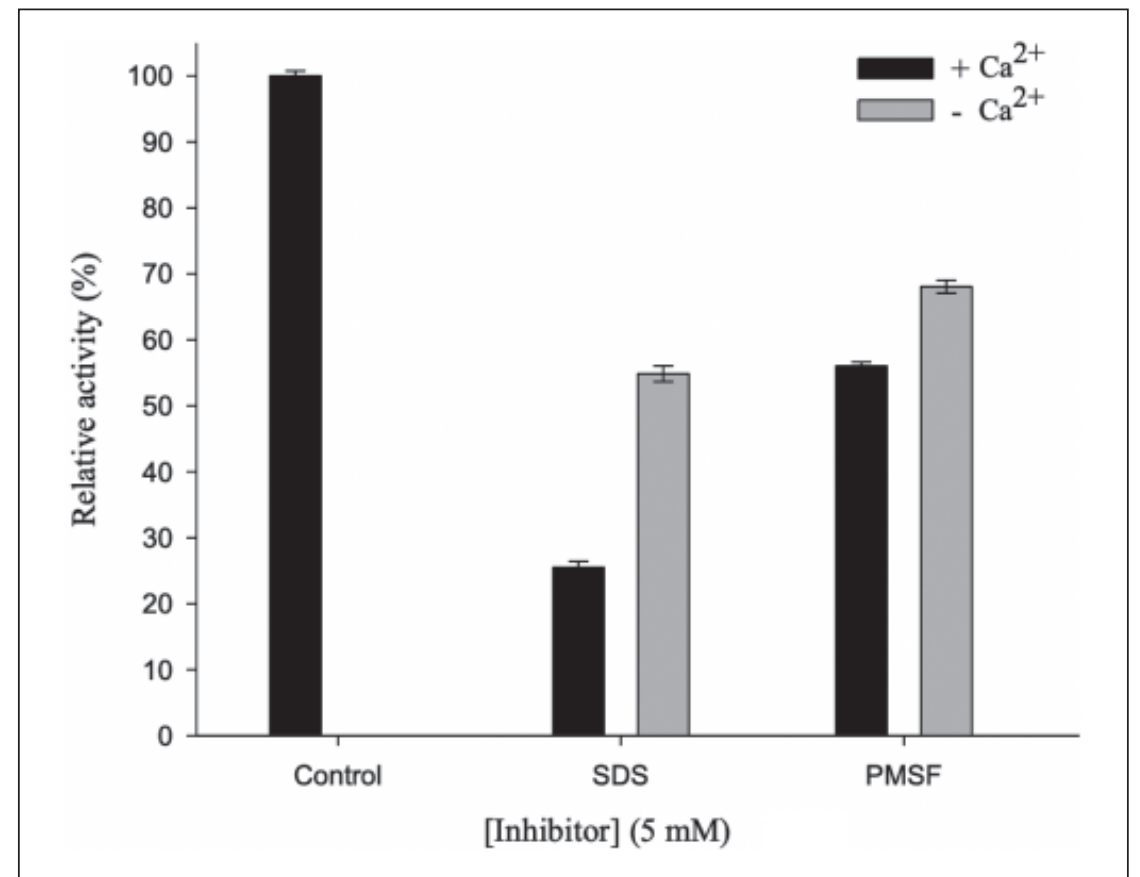

Fig 7. Profile of inhibitor dependence to the activity of lipase BK-AB4 at the condition presence and absence addition $\mathrm{Ca}^{2+}$ ion.

\section{ACKNOWLEDGEMENT}

This work was supported by the grant from the ministry of research, technology and higher education with the contract number of $310 \mathrm{u} / 11 . \mathrm{CO} /$ PL/2016 awarded to R.H.

\section{REFERENCES}

Asy'ari, M., Parwata, I.P., Aditiawati, P., Akhmaloka \& Hertadi, R. 2014. Isolation and Identification of Halostable Lipase Producing Bacteria from the Bledug Kuwu Mud Crater Located at purwodadi-Grobogan, Central Java, Indonesia, Journal of Pure and Applied Microbiology, 8(5): 3387-3396.

Bradford, M.M. 1976. A Rapid and Sensitif Method for The Quantitation of Microgram Quantities of Protein Utilizing The Principles of ProteinDye Binding, Journal Analytical Biochemistry, 72: $248-254$.

Gupta, R., Gupta, N. \& Rathi, P. 2004. Bacterial Lipases: an Overview of Production, Purification, and Biochemical Properties, Applied Microbiology Biotechnology, 64(6): 763-781.

Guzman, M.N., Vargas, V.A., Antezana, H. \& Svoboda, M. 2008. Lipolytic Enzyme Production by Halophilic/Halotolerant Microorganisms Isolated From Laguna Verde, Bolivia, Revista Boliviana De Quimica, 25: 14-23.
Hertadi, R. \& Widhyastuti, H. 2015. Effect of $\mathrm{Ca}^{2+}$ Ion to The Activity and Stability of Lipase Isolated from Chromohalobacter japonicus BKAB18, Procedia Chemistry, 16: 306-313.

Kanjanavas, P., Khuchareontaworn, S., Khawsak, P., Pakpitch Pothivejkul, K., Santiwatanakul, S., Matsui, K., Kajiwara, T. \& Chansiri, K. 2010. Purification and Characterization of Organics Detergent Tolerant Lipase from Thermotolerant Bacillus sp. RN2, International Journal of Molecular Sciences, 11: 3783-3792.

Lavanya, B. 2014. Metal ion activated lipase from halotolerant Bacillus sp. VITL8 displays broader operational range, International Journal of Biological Macromolecules, 67: 380386.

Lee, D., Koh, Y., Kim, B., Choi, H., Kim, D., Suhartono, M.T. \& Pyun, Y. 1999. Isolation and Characterization of Thermophilic Lipase from Bacillus thermoleovorans ID-1, FEMS Microbiology Letters, 179: 393-400.

Li, X. \& Yu, H. 2012. Characterization of a Novel Extracellular Lipase from a Halophilic Isolate, Chromohalobacter sp. LY7-8, African Journal of Microbiology Research, 6(1): 3516-3522.

Ozcan, B., Ozyilmas, G., Cokmus, C. \& Caliskan, M. 2009. Characterization of Extracellular Esterase and Lipase Activities From Five Halophilic Archaeal Strains, Journal of Industrial Microbiology Biotechnology, 36: 105-110. 
Pangesti, E.R. 2015. Isolasi dan Karakterisasi Lipase Stabil Detergen dari Bakteri Halofilik Kategori Sedang Halomonas eurihalina BK-AB15, Thesis Program Magister, Institut Teknologi Bandung, 3-20.

Parwata, I.P., Asy'ari, M. \& Hertadi, R. 2014. Organic Solvent-Stable Lipase from Moderate Halophilic Bacteria Pseudomonas stutzeri Isolated from the Mud Crater of Bledug Kuwu, Central Java, Indonesia, Journal of Pure and Applied Microbiology, 8: 31-40.

Pera, L.M., Romero, C.M., Baigori, M.D. \& Castro, G.R. 2006. Catalytic Properties of Lipase Extracts from Aspergillus niger, Journal Food Technology Biotechnology, 44: 247-252.

Sambrook, J. \& Russel, D.W. 2001. Molecular Cloning: A Laboratory Manual, Cold Spring Harbour Press, New York.
Scopes, R.K. 1994. Protein Purification: Principles and Practice ( $3^{\text {rd }}$ Edition), Springer Publisher, New York.

Soliman, N., Knoll, M., Abdelfattah, Y., Schid, R. \& Lange, S. 2007. Molecular Cloning and Characterization of Thermostable Esterase and Lipase rom Geobacillus thermoleovorans YN Isolated from Dessert Soil in Egypt, Process Biochemistry, 42: 1090-1100.

Uttatree, S., Winayanuwattikun, P. \& Charoenpanich, J. 2010. Isolation and Characterization of a Novel Thermophilic-Organic Solvent Stable Lipase From Acinetobacter baylyi, Applied Biochemistry Biotechnology, 44: 1113-1119.

Wehtje, E. \& Adlercreitz, P. 1997. Water Activity and Substrat Concentration Effect on Lipase Activity, Biotechnology Bioengineering, 55(5): 798-806. 
